\title{
PELATIHAN MYOB ACCOUNTING VERSION 19 PADA HIMPUNAN MAHASISWA PENDIDIKAN AKUNTANSI UNIVERSITAS PGRI MADIUN
}

\author{
Elly Astuti ${ }^{1}$ \\ ${ }^{1}$ Prodi Pendidikan Akuntansi, FKIP Universitas PGRI Madiun \\ Email: ellyastuti@unipma.ac.id
}

\begin{abstract}
The era of the industrial revolution had a huge corporate impact on business lines in various parts of the world. This has led to increasingly complex and rapid accounting developments. The process of making financial reports from traditional processes switches to integrated computerized systems. To harmonize the competency of graduates with the development of increasingly sophisticated accounting technology, training activities are carried out using the MYOB Accounting version 19. The MYOB Accounting version 19 applications was chosen because it combines basic accounting capabilities, computer applications and adequate understanding of English according to the needs of global competence.
\end{abstract}

Keywords: industrial revolution; MYOB Accounting; integrated learning

\section{Abstrak}

Era revolusi industri membawa dampak perusahaan yang sangat besar pada lini bisnis di berbagai belahan dunia. Hal ini mengakibatkan perkembangan akuntansi yang semakin kompleks dan pesat. Proses pembuatan laporan keuangan dari proses tradisional beralih ke sistem komputerisasi yang semakin terintegrasi. Untuk menyeleraskan kompetensi lulusan dengan perkembangan teknologi akuntansi yang semakin canggih, dilakukan kegiatan pelatihan penggunaan aplikasi MYOB Accounting version 19. Aplikasi MYOB Accounting version 19 dipilih karena memadukan kemampuan akuntansi dasar, aplikasi komputer serta pemahaman bahasa inggris yang memadai seuai dengan kebutuhan kompetensi global.

Kata Kunci: revolusi industri; $M Y O B$ Accounting; integrated learning

\section{PENDAHULUAN}

Era Revolusi Industri 4.0 membawa perubahan yang signifikan pada semua lini bisnis dan pola perilaku masyarakat. Pemanfaatan artificial intelligence yang semakin meluas, menjadikan bisnis berbasis IT berkembang semakin pesat. Perubahan tersebut juga memberikan dampak pada proses pelaporan keuangan perusahaan yang tepat waktu untuk pengambilan keputusan ekonomik secara memadai. Siklus akuntansi kini tidak lagi dikerjakan secara manual, banyak software yang ditawarkan untuk membantu proses penyusunan laporan keuangan secara cepat, tepat, dan akurat. Software akuntansi yang dikenal secara luas diantaranya MYOB Accounting, Accurate, Zahir, Bee Accounting, dan lain-lain.

MYOB Accounting merupakan software akuntansi yang berasal dari Australia dan sudah dikenal luas secara mendunia. Proses kegiatan pembelajaran komputer di Indonesia juga menggunakan software tersebut, bahkan pada tataran SMK penguasaan software tersebut menjadi salah satu uji 
kompetensi. Program Studi Pendidikan Akuntansi di Universitas PGRI Madiun yang merupakan pencetak calon guru akuntansi SMK di masa yang akan datang telah mempersiapkan kurikulum yang memadai atas penguasaan program tersebut. Namun demikian, beberapa tahun terakhir muncul wacana perubahan software yang akan digunakan uji kompetensi siswa SMK dari MYOB Accounting ke Accurate. Hal ini mempertimbangkan bahwa Accurate merupakan karya anak bangsa dan sangat cocok untuk diterapkan di Indonesia. Dalam upaya menjawab tantangan perubahan tersebut, Program Studi Pendidikan Akuntansi berusaha membekali mahasiswa dengan penguasaan kedua aplikasi yaitu MYOB dan Accurate secara seimbang.

Program pembelajaran komputer akuntansi yang sangat intensif dirasakan tetap kurang karena pendekatan kedua aplikasi yang sedikit berbeda. Dalam proses pembelajaran, MYOB dijadikan sebagai dasar pembelajaran sebelum mengenal Accurate. Hal ini dilakukan dengan pertimbangan bahwa dalam proses penyiapan data base MYOB Accounting memerlukan beberapa pertimbangan yang akan mengasah pemahaman akuntansi dasar mahasiswa. Hal ini sejalan dengan perkembangan IT dalam bidang akuntansi pada era revolusi industri 4.0, dimana bukan lagi ketepatan perhitungan dan angka yang dibutuhkan dalam proses penyusunan laporan keuangan, tetapi lebih kepada judgment apa yang mendasari pencatatan laporan keuangan.
Era revolusi industri memberikan tantangan kepada kita, agar memiliki keunggulan kompetitif. Seorang akuntan tidak hanya mengerti angka dalam laporan keuangan, tetapi lebih kepada whats behind the number. Kemampuan analisislah yang tidak dapat digantikan oleh mesin ataupun software. Walaupun semakin banyak software akuntansi yang akan menggantikan seorang akuntan dalam melakukan siklus akuntansi untuk mempersiapkan laporan keuangan, namun proses analisis dan asumsi tidak akan mampu tergantikan.

Berdasarkan analisis situasi dan pertimbangan sumber daya yang dimiliki, Himpunan Mahasiswa Pendidikan Akuntansi berinisitaif untuk memberikan pelatihan kepada pengurusnya untuk mempelajari MYOB lebih dalam. Gayung bersambut, inisiasi kegiatan ini didukung oleh Dosen pengampu komputer akuntansi yang nantinya menjadi instruktur dalam kegiatan pelatihan. Perwakilan mahasiswa yang mengkuti pelatihan, pada akhirnya diharapkan untuk menjadi tutor sebaya bagi teman-teman dikelasnya, sehingga pembelajaran MYOB Accounting semakin mudah diserap dan mahasiswa dapat mengembangkan wawasannya untuk mempelajari software-software akuntansi lainnya secara lebih luas.

\section{METODE PELAKSANAAN}

Program pelatihan dirancang untuk memberikan bekal pemahaman siswa atas penguasaan MYOB Accounting secara terintegrasi. Dengan mempertimbangkan alokasi waktu dan 
sumber daya yang relevan, kegiatan pelatihan dikemas secara efektif dan efisien dengan menggunakan pendekatan simulasi dan studi kasus. Studi kasus yang diberikan ketika pelatihan adalah siklus akuntansi perusahaan dagang. Kegiatan pelatihan juga ditunjang dengan buku praktikum yang telah disusun oleh instruktur.

Kegiatan pelatihan dilaksanakan pada 30 Desember 2018 diruang laboratorium pendidikan akuntansi Universitas PGRI Madiun sejak pukul 08.00 sampai dengan 17.00. Materi pelatihan dimulai dari persiapan data base perusahaan, input transaksi sampai dengan penyajian laporan keuangan. Persiapan data base perusahaan meliputi; membuat informasi awal, membuat daftar akun, membuat daftar pelanggan, membuat daftar pemasok, membuat daftar persediaan, mengisi saldo awal, melakukan seting pajak dan melakukan setting link account. Kegiatan dalam input transaksi adalah pemanfaatan fitur banking, purchase, sales, dan general journal entries. Sedangkan penyajian laporan keuangan adalah menampilkan hasil akhir laporan laba rugi, posisi keuangan, rekap buku besar dan laporanlaporan lain yang biasanya dibutuhkan oleh perusahaan. Proses pelatihan ini mengacu pada kegiatan pengabdian terdahulu yang dilakukan oleh (Zulfiar, Busra, Faisal, \& Mawaddah, 2018).

Peserta pelatihan adalah perwakilan kelas dari mahasiswa program Studi Pendidikan Akuntansi. Mahasiswa yang mengikuti pelatihan berjumlah 28 dari berbagai jenjang semester. Syarat peserta pelatihan adalah telah menempuh mata kuliah aplikasi komputer dan pengantar akuntansi. Sejalan dengan Pradhana \& Latifah (2013) yang menyatakan bahwa penguasaan dasar komputer berpengaruh signifikan terhadap penguasaan aplikasi MYOB. Di samping pengetahuan dasar komputer yang baik, mahasiswa juga harus memiliki pengetahuan yang memadai terkait akuntansi dasar. Bagaimanapun bagusnya sebuah sistem akan bergantung pada kompetensi yang menggunakannya. Informasi akan tepat dan bermanfaat bagi pengambilan keputusan sepanjang siklus akuntansi yang dilakukan telah memenuhi kaidah standar yang berlaku.

\section{HASIL DAN PEMBAHASAN}

Sebelum pelaksanaan pelatihan, instruktur memberikan overview untuk mengetahui sejauh mana pemahaman siswa mengenai fitur-fitur dasar komputer serta pemahaman mengenai akuntansi dasar. Berdsarkan review yang dilakukan instruktur, dapat ditentukan bagaimana cara menyampaikan materi penggunaan aplikasi secara tepat dan akurat. Berdasarkan review awal diketahui bahwa, sebagian besar peserta telah memiliki kompetensi yang cukup untuk melanjutkan pelatihan MYOB. Beberapa hal yang belum diketahui oleh siswa adalah perlakuan akuntansi untuk pembebanan kerugian piutang, transaksi pertukaran aset tetap dan perbedaan perlakuan akuntansi atas beberapa metode dalam melakukan penilaian persediaan.

Setelah kegiatan review, Instruktur mulai melakukan demonstrasi 
bagaimana proses membuat data perusahaan baru pada aplikasi MYOB Accounting version 19. Pada pengisian informasi umum perusahaan, peserta dapat mengikuti dengan baik. Namun ketika proses pembuatan daftar akun, peserta mulai menghadapi kendala pengelompokan akun. Kendala ini dihadapi karena kurangnya pemahaman dasar akuntansi keuangan. Di samping itu, MYOB Accounting version 19 menggunakan bahasa inggris, sehingga kemampuan bahasa inggris yang kurang turut mempengaruhi kemampuan analogi kelompok akun serta pengoperasian aplikasi MYOB Accounting (Pradhana \& Latifah, 2013). Fajarwati \& Listiadi (2018) dan Syofriani, Syofyan, \& Marwan (2018) juga mengungkapkan hal yang serupa yaitu kemampuan bahasa inggris yang baik didukung dengan kompetensi akuntansi keuangan yang memadai akan menghasilkan pemahaman dan keterampilan penggunaan aplikasi MYOB Accounting secara lebih baik.
Untuk mengatasi permasalahan kesenjangan kemampuan awal yang berdampak pada kegiatan pelatihan, instruktur memberikan demonstrasi kemudian memberikan pendampingan lebih intensif kepada peserta yang kurang mahir. Jika dirasa kurang cukup, atau sebagian besar peserta masih mengalami kebingungan, instruktur akan memberikan demonstrasi ulang secara perlahan-lahan. Instruktur juga meminta parsipasi dari peserta yang memiliki kemampuan lebih untuk mendampingi peserta lainnya. Kegatan ini dapat berjalan dengan efektif karena besarnya minat dan antusiasme mempengaruhi keberhasilan program (Kardiyem, Anisyukurillah, \& Sari, 2019).

Kegiatan pelatihan kemudian dilanjutkan pengisian saldo awal akun. Beberapa kendala yang dihadapi peserta pada tahap ini adalah kesalahan input saldo yang mengakibatkan nilai historical balancing tidak dapat 0 . Kesalahan yang sering dijumpai adalah peserta masih bingung dalam

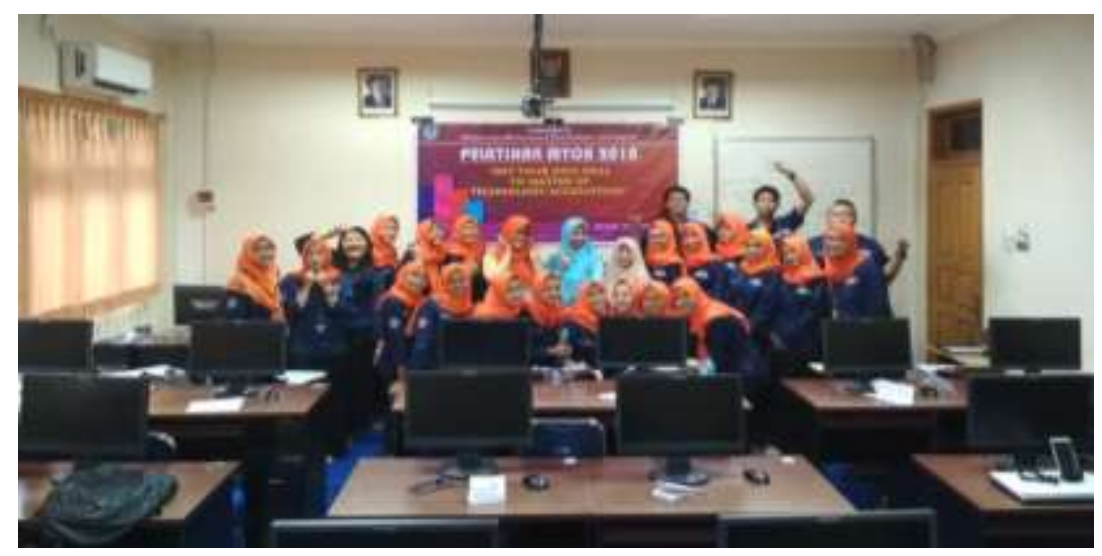

Gambar 1. Dokumentasi Kegiatan Pelatihan 


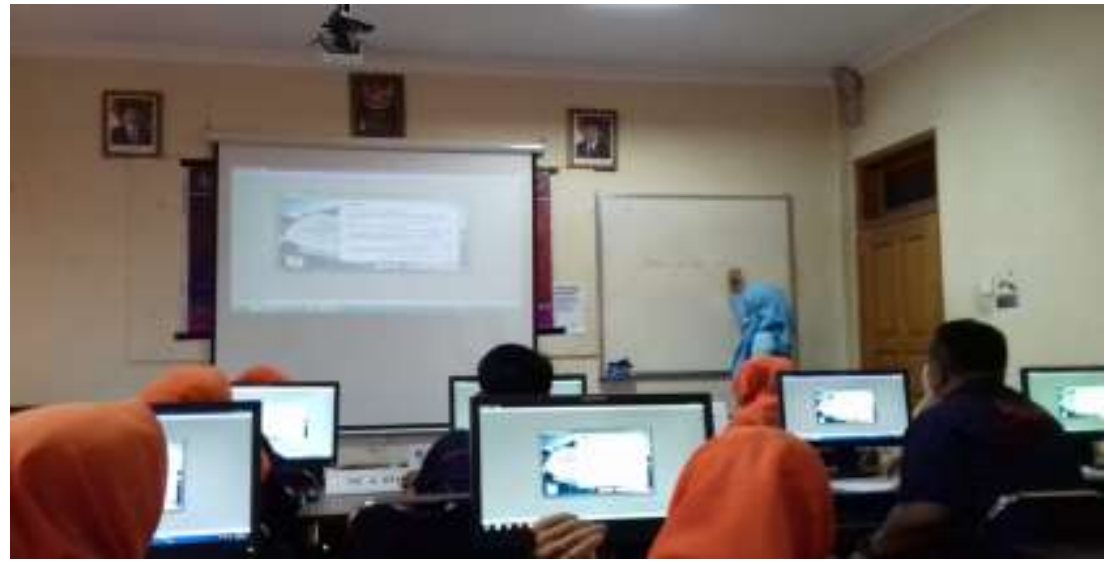

Gambar 2. Dokumentasi Kegiatan Pelatihan

menentukan saldo normal akun. Penentuan posisi saldo normal sangat diperlukan karena input saldo dalam MYOB version 19 tidak ada pembagian kolom debet dan kredit, semua dilakukan secara otomatis oleh sistem berdasarkan kelompoknya. Permasalahan akan terjadi untuk beberapa kontra akun seperti cadangan kerugian piutang, potongan pembelian, potongan penjualan dan beberapa kontra akun lainnya yang memiliki saldo normal bertentangan dengan kelompoknya. Ketika peserta diintruksikan untuk memberikan tanda minus pada kontra akun, mereka meiliki kecenderungan untuk input kelompok aset dalam nilai positif sedangkan kelompok liabilitas dan ekuitas dalam nilai negatif. Hal ini tentu memberikan dampak kesalahan yang cukup signifikan. Untuk itu, instruktur mengulang-ulang penjelasan mengenai input saldo berdasarkan saldo normalnya, bukan berdasarkan kelompoknya.

Materi pelatihan selanjutnya adalah pembuatan kartu pelanggan dan pemasok, pengisian saldo awal utang dan piutang, serta pembuatan persediaan lengkap dengan input saldo awalnya. Pada tahap ini instruktur harus benarbenar memandu dan memastikan bahwa syarat pembayaran dalam kartu utang dan piutang diinput dengan benar. Kesalahan input syarat pembayaran akan mengakibatkan kesalahan dalam jurnal yang dibuat karena adanya potongan yang tidak terecord oleh sistem. Peserta juga harus dingatkan untuk setting pajak pembelian dan penjualan barang dengan benar karena akan berdampak pada proses akhir bulan dalam perhitungan PPN terutang perusahaan.

Setelah inforrmasi umum perusahaan selesai diinput proses selanjutnya dalah input transaksi dalam beberapa fitur jurnal yang telah disedakan sistem. Pada tahap ini tidak ditemui kendala yang berarti. Para peserta dapat mengikuti instruksi yang diberikan dengan baik. Kesulitan peserta adalah proses pembuatan jurnal umum, karena membutuhkan analisis transaksi dan pemahaman mengenai perlakuan akuntansi yang sesuai. Pada tahap akhir penampilan dan cetak laporan keuangan dapat dilakukan peserta dengan baik. 
Secara umum, peserta dapat mengoperasikan MYOB Version 19 dengan baik. Peserta juga dapat menghubungkan antara pemahaman mengenai dasar akuntansi keuangan terhadap penggunaan aplikasi MYOB Accounting version 19. Kompetensi penguasaan MYOB version 19 sangat bergantung pada motivasi internal peserta (Suharyono, 2018). Semakin tinggi minat dan antusiasme peserta untuk belajar, berdampak pada peningkatan kompetensi peserta secara signifikan(Kardiyem et al., 2019).

\section{PENUTUP}

Kegiatan pelatihan ditujukan untuk memberikan ketrampilan dasar penggunaan aplikasi MYOB Accounting version 19 kepada perwakilan mahasiswa yang tergabung dalam Himpunan Mahasiswa Pendidikan Akuntansi Universitas PGRI Madiun. Berdasarakan kegiatan pelatihan yang telah dilakukan dapat disimpulkan bahwa MYOB memberikan kualitas yang baik bagi pengguna aplikasi komputer akuntansi dasar. Hal ini sejalan dengan Kristanto dan Widyan (2017) yang menyatakan bahwa kualitas sistem MYOB Accounting berpengaruh positif terhadap kinerja pengguna tingkat dasar yaitu mahasiswa.

$$
\text { Pelatihan aplikasi MYOB }
$$
Accounting memperluas wawasan mahasiswa dalam integrasi ilmu akuntansi dasar yang dipelajari dengan software terkait. Setelah pelatihan dan proses pengerjaan studi kasus, hampir semua peserta dapat mengoperasikan MYOB Accounting dengan baik.
Keberhasilan program juga ditunjang oleh fasilitas Laboratorium Program Studi Pendidikan Akuntansi Universitas PGRI Madiun yang memadai. Ketersediaan fasilitas yang menunjang mampu meningkatkan prestasi belajar siswa (Safitri \& Setiyani, 2016). Ketersediaan buku referensi di perpustakaan Program Studi Pendidikan Akuntansi Universitas PGRI Madiun yang lengkap juga semakin mendukung kesuksesan program ini. Hal ini sejalan dengan Yuniarta (2008) yang menyatakan bahwa metode pembelajaran dengan problem based learning yang didukung ketersediaan modul ajar akan meningkatkan aktivitas belajar mahasiswa yang berdampak pada peningkatan hasil belajar siswa serta peningkatan profesionalisme dosen.

Untuk kegiatan pengabdian masyarakat tentang pelatihan penggunaan aplikasi di masa yang akan datang sebaiknya instruktur membuat video tutorial yang dapat diunduh peserta sebelum kegiatan pelatihan sehingga dapat mengurangi kesenjangan pemahaman antar peserta. Kesetaraan pemahaman awal tentu berdampak pada efektivitas program pelatihan. Giovani, Hidayat, \& Mariam (2018); Mema (2013); dan Syofriani et al. (2018) menyatakan bahwa semakin penggunaan media tutorial dapat meningkatkan kemandirian dan hasil pembelajaran MYOB Accounting mahasiswa.

\section{DAFTAR PUSTAKA}

Fajarwati, T., \& Listiadi, A. (2018). Pengaruh Penguasaan Pengantar Akuntansi, Bahasa Inggris Dan 
Fasilitas Laboratorium Terhadap Hasil Belajar Komputer Akuntansi Myob Siswa Kelas XI Akuntansi Smk Negeri 1 Lamongan. Jurnal Pendidikan Akuntansi, 6(2), 126130.

Giovani, C. D., Hidayat, A., \& Mariam, P. (2018). Pemanfaatan Video Tutorial MYOB terhadap Ketrampilan Siswa dalam Mengoperasikan Aplikasi Komputer Akuntansi. Jurnal Pendidikan Dan Pembelajaran Ekonomi Akuntansi, 4(2), 89-100.

Kardiyem, Anisyukurillah, I., \& Sari, P. N. (2019). Profesionalisme Guru Mgmp Akuntansi Smk Kota Semarang Melalui Transformasi. Jurnal PANJAR, 1(1), 70-74.

Mema, N. (2013). Kemandirian dan Hasil Belajar Siswa Pada Mata Pelajaran Komputer Akuntansi Dengan Menggunakan Media Tutorial Myob Berbasis Adobe Captivate. Journal of Accounting and Business Education.

Pradhana, D. Y., \& Latifah, L. (2013). Pengaruh Kosa Kata Bahasa Inggris, Dasar Komputer Dan Akuntansi Terhadap Prestasi Belajar Myob. Jurnal Pendidikan Ekonomi Dinamimika Pendidikan, $\operatorname{VIII}(2), 75-84$.
Safitri, M. E., \& Setiyani, R. (2016). Pengaruh Motivasi Belajar, Computer Attitude dan Fasilitas Laboratorium Akuntansi Terhadap Prestasi Belajar Akuntansi MYOB. Economic Education Analysis Journal, 5(1), 30-43.

Suharyono. (2018). Pengaruh Myob Test Clinic Terhadap Kompetensi Mahasiswa. Jurnal Analisa Akuntansi Dan Perpajakan, 2(September), 54-64.

Syofriani, Syofyan, E., \& Marwan. (2018). The Effect of Tutorial Video Use and Prerequisite Skills on Students ' MYOB Accounting Performance. 1st International Conference on Economics Education, Economics, Business and Management, Accounting and Entrepreneurship, 57(Piceeba), 636-641.

Yuniarta, G. A. (2008). Pengembangan Problem Based Learning Dengan Myob Accounting Pada Mata Kuliah Komputer AkuntansI. Jurnal Pendidikan Dan Pengajaran, 41(1), 1-19.

Zulfiar, E., Busra, Faisal, \& Mawaddah, N. (2018). Pelatihan Aplikasi MYOB Accounting Bagi Siswa SMK Negeri 5 Kota Lhokseumawe C-1 C-2. Proceeding Seminar Nasional Politeknik Negeri Lhokseumawe, 2(1), 1-4. 